\title{
Blue Ocean Strategy: A Panacea to the Menace of Bureaucratic Corruption in Nigeria
}

\author{
Mohammed Musa W. Kirfi (PhD) ${ }^{1}$, Ishola Abdulrasaq Ajadi ${ }^{2}$ \\ ${ }^{1}$ Department of Public Administration, Usmanu Danfodiyo University, Sokoto, Nigeria \\ ,$^{2}$ Graduate at UDUSOKOTO, Nigeria
}

\begin{abstract}
The misplacement of official interest for personal benefit that has characterized the Nigeria bureaucratic settings has in no small way curtailed the extent to which national development is achieved. Blue ocean strategy represents an alternative approach to the conduct of public business in such a way it blocks all the major avenues for looting public treasury as well as the enhancement of effective and efficient service delivery. Exploring the current failures in our health institutions it appears that numerous factors have continued to militate against their effective service quality. Despite the huge amount of money voted yearly for the development of the health sector in the national budget, the sector has remained a mere shadow of itself. This paper adopts a stratified sampling technique and use questionnaire to extract response from the respondents. The result of the analysis reveals that the level of corrupt practices in the health sector has led to the diversion of fund from the procurement of medical equipment to private pockets, hence the inadequacies of medical equipment in the various public health institutions.). It is therefore recommended that stewardship function and improved management support system should be incorporated in the activities of the public service.
\end{abstract}

Keywords: Blue-ocean Strategy, Bureaucracy. Bureaucratic Corruption, Health Systems and ServiceDelivery

\section{Introduction}

Corruption has been a major problem facing Nigerian society and other third world countries since independence. Although, corruption is a major problem in Africa, it is not peculiar to the continent and the depth if the problem vary from region to region, between and among states and across time (Oganye, 2009; Bolarinwa and Aderogba, 2009). Corruption is a huge challenge in the public administration in Nigeria. It is at the core of the crisis of governance and legitimacy, the establishment of a stable democratic order, rule of law, development and the welfare of citizens (Ogundiya, 2009). It exists in all countries, both developed and developing, in the public and private sectors, as well as in non-profit and charitable organizations (Myint, 2000). The extent to which millions of naira is going down the drain in the corridor of governance has prompted the search for a better and lasting approach to the menace. The instrument through which services are been delivered (i.e. the civil service) to the populace has also fell victim as a viable channel through which public resources is been siphoned.

Corruption that occurs in public administration and government services is a common feature in the land sector (Transparency International, 2011). Any attempt to understand the tragedy of development and the challenges to democracy in most developing countries (Nigeria inclusive), must come to grips with the problem of corruption and stupendous wastage of scarce resources. This is not to suggest that corruption and prodigality are peculiar to the developing countries. Certainly, corruption is neither culture specific nor system bound. It is ubiquitous. However, the severity and its devastating impact vary from one system to the other. The impact is undoubtedly more severe and devastating in the developing world with weak economic base, fragile political institutions and inadequate control mechanisms (Ogundiya, 2009).

We are all part of the cycle of corruption and despair and we must join hands to root out this evil that is strangling our nation (Aroyo, c.f. Oosterbroek, 2007:5). In recent years, billions of Naira has been spent to organize seminars, debates, and conferences to proffer solutions as to ways of managing the menacing effects of corrupt acts of public officials. In spite of these efforts by government, corruption management is still dismal (Iroghama, 2011). The submission of the classical economist opined that competition will be a viable tool through which efficiency can be achieved while fresh writers like Ted and Gabbler (1992) suggest the New Public Management as a tool of upgrading the performance of the public sector. The Clinton administration pursued the re-inventing government rigorously but yet, the devastating epitomes of bureaucratic corruption were still glaring. Corruption can be a major obstacle in the process of economic development and in modernizing a country. Many now feel that it should receive priority attention in a country's development agenda (Myint, 2000). 
The Blue ocean strategy was designed to create new focus and approach to combating bureaucratic inefficiency. Kim \& Mauborgne (2004) identified; creating an uncontested market, making of competition irrelevant, creating and capturing of new demands, break the value/cost trade-off and aligning the whole system of a company's activities in pursuit of differentiation and low cost as the basic principles that guide the adoption of the blue ocean strategy. The dominant role played by the government in some national activities needs to be abandoned and the available public fund diverted elsewhere to areas of little patronage.

This paper will therefore examine the possibility of pasting these tenets of the blue ocean strategy in the configuration and management of Nigeria's bureaucracy in an attempt to halt the perpetuation of corrupt practices through its activities.

\section{Conceptual Clarification}

In order to critically explore this study, certain concepts will need to be critically examined. Those concepts are;

1. Blue ocean strategy

2. Bureaucracy

3. Corruption

\section{Blue Ocean Strategy}

The rate at which scholars has paid attention to the concept of blue ocean strategy is very low. This does not signify its insignificance in academia but due to its recency and so, few submissions on the concept will be examined. Before exploring the basic idea behind the concept of blue ocean strategy, there is the need to shed some light on the term "strategy". In doing this, we need to know what strategy is and how an effective strategy is put in place, since there are many misunderstandings about the topic of organizational strategy, let's define what strategy is not. Strategy is not about operational effectiveness -- trying to be better, faster, or cheaper than a competitor. This is simply being more efficient than competitors. Nor is strategy about benchmarking or trying to do the same things as your competitor but doing them better. This may lead to short term advantage at best. Strategy is also not about trying to be number one in a given market. That is a statement of aspiration that simply defines how well you want to do, not what you want to do (Porter,). So what is strategy?

Strategy is the process of competing to be unique rather than competing to be the best, although a military background has been traced to the term but it has been adopted more widely in organizational management. It involves defining a unique value proposition through which the organization will achieve and maintain competitive advantage. It involves developing a different and tailored "value chain" or set of activities that support and help to differentiate the organization's strategy. It involves deciding what not to do as much as what to do. The Longman Dictionary of Contemporary English, Third Edition sees strategy as "a well-planned series of actions for achieving an aim, especially success against an opponent or threat".

In order to critically explore the concept of blue ocean strategy, the term "Red oceans" will as well be examined. The metaphor of red and blue oceans describes the market universe. Red oceans are all the industries in existence today- the known market space. In the red oceans, industry boundaries are defined and accepted, and the competitive rules of the game are known. Here companies try to outperform their rivals to grab a greater share of the product or service demand. As the market space gets crowded, prospects for profits and growth are reduced. Products become commodities or niche, and cutthroat competition turns the ocean bloody. Hence, the term red oceans. Blue oceans, in contrast, denote all the industries not in existence today-the unknown market space, untainted by competition. In blue oceans, demand is created rather than fought over. There is ample opportunity for growth that is both profitable and rapid. In blue oceans, competition is irrelevant because the rules of the game are waiting to be set. Blue Ocean is an analogy to describe the wider, deeper potential of market space that is not yet explored (Kim and Mauborgne, 2005). Although the term may be new, blue oceans have always been with us (Kim and Mauborgne, 2005). Today, one hardly talks about strategy without using the language of competition. The term that best symbolizes this "competitive advantage worldview, companies are often driven to out-perform rivals and capture greater shares of existing market space. Of course, competition matters. However, by focusing on competition, scholars, companies, and consultants have ignored two very important and, we would argue, far more lucrative-aspect of strategy: one is to find and develop markets where there is little or no competition-blue oceans- and the other is to exploit and protect blue oceans. These challenges are very different from those to which strategists have devoted most of their attention.

Blue oceans are not about technology innovation. Leading-edge technology is sometimes involved in the creation of blue oceans, but it is not a defining feature of them. Perhaps the most important feature of blue ocean strategy is that it rejects the fundamental tenet of conventional strategy: that a trade-off exits between value and cost. A rejection of the trade-off between low cost and differentiation implies a fundamental change in strategic mind-set. We cannot emphasize enough how fundamental a shift it is. The red ocean assumes that 
industry's structural conditions are given and firms are forced to compete within them. This is based on an intellectual worldview that academicians call the structural view, or environmental determinism. According to this view, companies and managers are largely at the mercy of economic forces greater than themselves. Blue ocean strategies, by contrast, are based on a world-view in which market boundaries and industries can be reconstructed by the actions and beliefs of industry players. We call this the re-constructionist view.

A blue ocean is created in the region where a company's actions favourably affect both its cost structure and its value proposition to buyers. Cost savings are made from eliminating and reducing the factors an industry competes on. Buyer value is lifted by raising and creating elements the industry has never offered. Over the time cost are reduced further as scale economics kicks in, due to the high sales volumes that superior value generates. In blue oceans, demand is created rather than fought over. There is ample opportunity for growth that is both profitable and rapid. In summary, blue ocean strategy is mainly on "how to create uncontested market space and make competition irrelevant" as well as "going to where profits and growth are and where the competition isn't'".

\section{Bureaucracy}

Bureaucracy is a term coined and popularized by Max Weber in the $19^{\text {th }}$ century to mean "the principle of official jurisdictional areas, which are generally ordered by rules, that is, by laws or administrative regulations" (Weber, 1968). To most people, "bureaucracy" is a fighting word. Few things are more disliked than bureaucracy, few occupations held in lower esteem than the bureaucrat. Both are subjected to repeated criticism in the press and damned regularly by political soap box orators and ordinary citizens. "Inefficiency," "red tape," "stupidity," "secrecy," "smugness," "aggressiveness," and "self-interest" are only a few of the emotionally charged words used to castigate bureaucrats.

From the standpoint of public administration and social science literatures in general, "bureaucracy" means much more than the various bothersome characteristics of modem organizations. The term in serious administrative literature denotes the general, formal structural elements of a type of human organization, particularly a governmental organization. In this sense bureaucracy has both good and bad qualities; it is a neutral term rather than one referring to only the negative traits of organizations. It is a lens through which we may dispassionately view what Carl Friedrich has appropriately tagged "the core of modem government."

The German social scientist, Max Weber (1864-1920), is generally acknowledged to have developed the most comprehensive, classic formulation of the characteristics of bureaucracy. Weber not only pioneered ideas about bureaucracy but ranged across a whole spectrum of historical, political, economic, and social thought.

\section{Corruption}

Increasing public interest and concern over corruption have resulted in a large amount of scholarly research on the subject. Admittedly, there are still wide gaps in the current state of information and knowledge on the matter and much more remains to be done. Almost every theorist who has attempted to defined corruption has at first instant recognized the difficulty in the task (Miis Liiv, 2004). Despite an abundance of research on corruption, there is no real consensus on what corruption is (Ogundiya, 2011). Nevertheless, theoretical and empirical research that has been conducted thus far has yielded fresh insights into the problem (Myint, 2000). The systematic study of corruption is hampered by the lack of an adequate definition (Peters 1978, Johnston 1991, Brinkerhoff 2000, Izibili and Aiya 2007). Studying corruption, writes Johnston (1991:48), is a tricky business as he comments that

"Definitions are controversial, and solid evidence is often elusive. Descriptive accounts may be clouded by self-serving equivocations. Equally subtle is the question of the significance of a corrupt act-not only its consequence, but also its meaning as perceived by citizens and officials alike" (C.f. Ogundiya, 2009).

In the light of the above submission, Corruption has received an extensive attention in the communities, and perhaps, due to the fact that it has been over-flogged in the academic circles, corruption has received varied definitions which differ depending on the discipline and mechanism used to explain the phenomenon (Johnston, 1996:333). There is a growing worldwide concern over corruption at the present time (Myint, 2000). Corruption in public procurement which affects countries across the globe has enormous negative consequences. It diverts public funds into unnecessary, unsuitable, uneconomic or even dangerous projects (Aizawa, 2008). Corruption is defined as the use of public office for private gain, or in other words, use of official position, rank or status by an office bearer for his own personal benefit. Following from this definition, examples of corrupt behaviour would include: (a) bribery, (b) extortion, (c) fraud, (d) embezzlement, (e) nepotism, (f) cronyism, (g) appropriation of public assets and property for private use, and (h) influence peddling (Myint, 2000).

Ramatu (2008), put the term as "encompassing unilateral abuses by government officials such as embezzlement and favoritism as well as abuses linking public and private sectors such as bribery, extortion, 
influence peddling and fraud. Corruption is a behavior which deviates from the formal duties of a public role, because of private [gains] - regarding (personal, close family, private clique, pecuniary or status gains. It is a behavior which violates rules against the exercise of certain types of [duties] for private [gains] - regarding influence (Nye, 1967) c.f. Dike. A more recent version with the same elements is found in the definition by Mushtaq Khan, who defines corruption as 'behaviour that deviates from the formal rules of conduct governing the actions of someone in a position of public authority because of private-regarding motives such as wealth, power or status' (Khan, 1996, pp.12 c.f. Oosterbroek, 2007). Incidence of corruption varies among societies, and it can be rare, widespread or systemic. When it is rare, it is relatively easy to detect, isolate and punish and to prevent the disease from becoming widespread. When corruption becomes widespread, it is more difficult to control and to deal with. But the worst scenario is when it becomes systemic. When systemic corruption takes hold of a country, the institutions, rules and peoples' behaviour and attitudes become adapted to the corrupt way of doing things, and corruption becomes a way of life. Systemic corruption is very difficult to overcome and it can have a devastating effect on the economy (Myint, 2000).

The level of corruption varies across countries according to the national legislation and custom (Oosterbroek, 2007). Myint, (2000) posits that, Corruption can involve various actors, ranging from public officials and local leaders to outside investors. Actors may include government officials (at the local and national level) as well as individuals that command political and economic power. Customary and communal authorities may also be involved, engaging in corrupt dealings and practices.

\section{Bureaucratic Corruption in Nigeria}

There are many unresolved problems in Nigeria, but the issue of the upsurge of corruption is troubling. In addition, the damages it has done to the polity are astronomical. The menace of corruption leads to slow movement of files in offices, police extortion tollgates and slow traffics on the highways, port congestion, queues at passport offices and gas stations, ghost workers syndrome, election irregularities, among others. Even the mad people on the street recognize the havoc caused by corruption - the funds allocated for their welfare disappear into the thin air. Thus, it is believed by many in the society that corruption is the bane of Nigeria. Consequently, the issue keeps reoccurring in every academic and informal discussion in Nigeria. And the issue will hardly go away! (Dike). Corruption has been discovered to take two major directions when it is been discussed in relation to government, i.e. political corruption and bureaucratic corruption. The problem of Bureaucratic and political corruption have been a long drawn issue in Nigerian politics it has been acknowledge by several observers of Nigerian politics as hidden disease of democracy and blight of development in the Country (Ekeh, 1985; Obayelu, 2007; Diamond, 1991; Falaha, 2007; Oyelowo, 2009). Ogundiya (2009), further stressed that "The pathological effects of corruption-democratic instability, low level of governmental legitimacy, voracious poverty, infrastructural decay, electoral crisis, contract killing, political assassination, insecurity and generally, developmental problems- have been very devastating. The fact that corruption is anathema to all forms of development is not elusive to the successive Nigerian rulers both military and civilian. What was astonishing is the fact that most of them (the Nigerian rulers) that came in as physicians have come out as patients (Ogundiya, 2009). Allegations and charges of corruption now play a more central role in politics than at any other time. Governments have fallen, careers of world renowned public figures ruined, and reputations of well-respected organizations and business firms badly tarnished on account of it (Myint, 2000).

Corruption can have undesirable consequences on both the revenue and expenditure sides of the government budget (Myint, 2000). Although many people think of corruption as a phenomenon which can only have negative consequences there are also some theories about positive effects that may occur. One of the positive effects, some argue, is that it helps to overcome bureaucratic rigidities and helps to maintain allocation efficiently. There are some forms of competition going on between bribers. Small payments can be a motivation for officials to speed up the bureaucratic process which promotes economic growth. Unfortunately, research fails to support the assumption that it speeds up the process for petty corruption. Corruption still can be considered slowing down the apparatus of the state; however it still can have a positive effect because some incidences of bribery have a positive influence on the time that managers of international firms have to spend with bureaucrats. It is argued that once bureaucrats realize the potential for increasing their income through petty corruption they create more rules that require increased interaction between the managers and the bureaucracy. Another possibility is that the bureaucrats refuse to provide 'free' government services for free. So there are many reasons why the efficiency of the bureaucratic process does not improve even if the speed of the transaction increases. The number of required transactions in the presence of bribery may increase sufficiently to offset the efficiency by which each transaction in general is carried out.

It also has to be noticed that petty corruption normally does not exist solely but that it is part of a much larger network of payments. These larger networks can lead to many other distortions of the economy caused by the safeguarding of the positions of those officials and bureaucrats who benefit from petty corruption. One can conclude that most academic researcher believe that corruption does not aid development in certain instances 
because of a lack of evidence that localized petty corruption can survive without serious effects on the rest of the economy or that it has some other positive impact on the economy in a general equilibrium framework (Jain, 2001, pp. 92-93) c.f. (Oosterbroek, 2007:19-20).

When one considers the economic consequences of corruption, the adverse impact of grand corruption comes readily to mind. Corruption on a grand scale associated with some dictators and their cronies can involve embezzlement of huge sums of public funds, and the mismanagement, wastage, inequity, and social decay that come along with it, can be disastrous for an economy. There are familiar tales of fortunes in gold, gems and jewelry stashed away in secret hiding places by corrupt officials and hundreds of millions of dollars spent in acquiring real estate abroad and in depositing into their foreign bank accounts. The devastating impact of misconduct on such a massive scale, especially for poor countries that are facing perennial and severe foreign exchange shortages, is obvious and requires no further comment. But corruption does not have to be on a grand scale to inflict serious damage. There are other adverse effects that can be just as damaging for a poor country (Myint, 2000).

Although corruption exists in all countries it is more widespread in low income countries. This is not because people in poor countries are more corruptible than their counterparts in rich countries. It is simply because conditions in poor countries are more conducive for the growth of corruption. Bribery and graft are crimes of calculation and not of passion. Hence, when benefits are large, chances of getting caught are small, and penalties when caught are light, then many people will succumb.

\section{Methodology}

The population of the study consists of all the employees of the Usmanu Danfodiyo University Teaching Hospital (UDUTH) and Sahel Specialist Hospital, Sokoto as well as their clients (NHIS clients). This will include those directly employed by the government and those sourced through out-sourcing method of recruitment. The population of the study thereby amount to Nine thousand, six hundred and fifty seven (9657).

TABLE: 1.1 POPULATION OF THE STUDY BY CATEGORIZATION.

\begin{tabular}{|l|l|l|l|l|}
\hline S/N & INSTITUTION & SER VICE PROVIDERS & CLIENTS & TOTAL \\
\hline 1 & UDUTH & 2,103 & 6840 & 8943 \\
\hline 2 & SAHEL & 30 & 684 & 714 \\
\hline & TOTAL & 2133 & 7524 & 9657 \\
\hline
\end{tabular}

\section{Sample Size and Sampling Techniques}

Due to the difficulties associated with taking the entire population for a study, and in line with the scientific tradition, the sample of the study shall be calculated using the Sample size calculator as designed by Raosoft, Inc. A total of three hundred and seventy respondents shall be considered in this study and stratified sampling technique was adopted in the selection of the respondents.

TABLE: 1.2 SAMPLE SIZE OF THE STUDY BY THE SAMPLE SIZE ONLINE CALCULATOR

\begin{tabular}{|l|l|}
\hline Margin of error & $5 \%$ \\
\hline Confidence level & $95 \%$ \\
\hline Population size & 9657 \\
\hline Response distribution & $50 \%$ \\
\hline Recommended sample & 370 \\
\hline
\end{tabular}

Source: Authors' computation using Raosoft sample size online calculator

> The chance of $43.33 \%$ is based on the adopted work of J.W. Oosterbroek (2007)

$>43.33 \%$ is scientifically representative and statistically significant.

\section{Data Analysis Methods}

The information gathered from the respondents through the questionnaire formed the basis for data coding and analysis in the study. The descriptive statistics of simple frequency count and simple percentage were used for description and analysis. To test the hypotheses formulated, chi-square method is employed. This method is used because it is good in testing the validity of the hypothetical statement especially to study the relationship between two or more variables.

\section{Data Presentation and Analysis}

This section presents and analyzes the data gathered in the course of this research. A total of three hundred and seventy (370) questionnaires were distributed to four categories of respondents. Only three hundred and 
twelve (312) were returned implying $84.3 \%$ as the response rate. The analyses will be conducted based on initial statement, evidence from the table, personal observation and literature/empirical evidence as appropriate.

\section{TABLE 1.3 Questionnaires: Section A}

\begin{tabular}{|c|c|c|c|}
\hline $\mathbf{S} / \mathbf{N}$ & Variable & Number & Percentage $\%$ \\
\hline 1 & $\begin{array}{l}\text { Male } \\
\text { Female } \\
\text { Fem } \\
\end{array}$ & $\begin{array}{l}189 \\
123\end{array}$ & $\begin{array}{l}61 \\
39 \\
\end{array}$ \\
\hline 2 & $\begin{array}{l}\text { Marital Status } \\
\text { Married } \\
\text { Single }\end{array}$ & $\begin{array}{r}247 \\
65 \\
\end{array}$ & $\begin{array}{l}79 \\
21 \\
\end{array}$ \\
\hline 3 & $\begin{array}{l}\quad \text { Educational qualification } \\
\text { Primary certificate } \\
\text { Secondary certificate } \\
\text { OND/ NCE } \\
\text { HND/ B. Sc } \\
\text { Others (Specify) } \quad \text { M. Sc } \\
\end{array}$ & $\begin{array}{r}12 \\
56 \\
45 \\
148 \\
51 \\
\end{array}$ & $\begin{array}{c}4 \\
18 \\
14 \\
47 \\
17 \\
\end{array}$ \\
\hline 4 & $\begin{array}{l}\quad \text { Years of Service } \\
\text { Dependents } \\
1-4 \\
5-15 \\
16-25 \\
26 \text { and above } \\
\end{array}$ & $\begin{array}{c}41 \\
84 \\
109 \\
53 \\
25 \\
\end{array}$ & $\begin{array}{r}13 \\
27 \\
35 \\
17 \\
8 \\
\end{array}$ \\
\hline 5 & $\begin{array}{l}\quad \text { Category of Staff } \\
\text { Skilled } \\
\text { Unskilled } \\
\text { Clients }\end{array}$ & $\begin{array}{r}107 \\
81 \\
124 \\
\end{array}$ & $\begin{array}{l}34 \\
26 \\
40\end{array}$ \\
\hline 6 & $\begin{array}{l}\quad \text { Categories of Respondents } \\
\text { Service providers } \\
\text { UDUTH } \\
\text { SAHEL } \\
\text { Clients } \\
\text { MAIN } \\
\text { SUBSIDIARY }\end{array}$ & $\begin{array}{r}161 \\
27 \\
\\
83 \\
41\end{array}$ & $\begin{array}{c}52 \\
9 \\
\\
26 \\
13\end{array}$ \\
\hline
\end{tabular}

Source: Field work, 2012.

The table above shows that 189 out of 312 respondents are male while 123 are female. This means that $61 \%$ of the respondents involved in this study are male while $39 \%$ of them are female. It is also clearly shows that 65 respondents involved in this study are single while 247 are married. Analysis in a simple percentage calculation shows that $21 \%$ involved in this study are single while $79 \%$ are married. It went further to show the qualification of the respondents, as those with primary certificate are 12 out of the 312 respondents, secondary certificate 56, Diploma/NCE 45, B.sc / HND 148 and 51 M.sc holders. This was analyzed as 4\%, 18\%, 14\%, $47 \%$, and $17 \%$ respectively.

On the respondent's years of service, the table shows that 41 of the respondents are dependents (i.e. wards of NHIS clients), 84 are between the service years of 1-4, and 109 respondents are between 5-15, 53 between 16-25 while 25 are between the service year of 26 and above. This means that $13 \%$ of the respondents are minor/ dependents, $27 \%$ are between the service year of $1-4,35 \%$ falls between $5-15,17 \% 16-25$ while $8 \%$ between 26 and above of the total respondents. The category of staff indicates that 107 of the respondents are skilled workers, 81 are unskilled while 124 are clients which can be analysis as 34\%, 26\% and $40 \%$ respectively.

The table later shows that 161 out of 312 respondents are from UDUTH, 27 from Sahel hospital, 83 respondents are the main clients while the remaining 41 respondents are Subsidiary clients. This gives $52 \%, 9 \%$, $26 \%$ and $13 \%$ of the total respondents respectively. This has clearly created a little insight into the caliber of respondents selected as sample for this study.

Table 1.4

Do you think there is mismanagement of funds in the public health sector?

\begin{tabular}{|l|c|l|}
\hline Response & No. Respondents & Percentage \% \\
\hline Yes & 213 & 68.3 \\
\hline No & 31 & 9.9 \\
\hline No response & 68 & 21.8 \\
\hline Total & $\mathbf{3 1 2}$ & $\mathbf{1 0 0}$ \\
\hline
\end{tabular}

Source: Field work, 2012.

From the table above, 213 respondents translating to $68.3 \%$ of the total respondents opined that there is mismanagement of fund in the public health sector, 31 respondents representing $9.9 \%$ of the respondents held the view that there is no mis-management of fund. $21.8 \%$ amounting to 68 respondents did not give any response. 
The interpretation of the above table clearly shows that there is gross mis-management of fund in the public health sector and these agree with the submissions of Oganye, (2009), Bolarinwa and Aderogba, (2009). The researcher observed that this financial scandal cut across the activities of both the bureaucrats as well as those holding political positions relating to the health sector.

Table 1.5 To what extent will you agree that excessive funding lead to corruption in the public health care sector?

\begin{tabular}{|l|c|c|}
\hline Response & No. Respondents & Percentage \% \\
\hline Very great extent & 61 & 19.6 \\
\hline Great extent & 23 & 7.4 \\
\hline In no way & 207 & 66.3 \\
\hline Don't know & 21 & 6.7 \\
\hline Total & $\mathbf{3 1 2}$ & $\mathbf{1 0 0}$ \\
\hline
\end{tabular}

Source: Field work questionnaire 2012.

Citing from the table above, $19.6 \%$ of the respondents translating to 61 respondents regarded excessive government funding has been a cause of corruption to a very great extent, 23 respondents representing $7.4 \%$ of the total respondents view excessive funding as being a possible cause of corruption to an extent. $66.3 \%$ amounting to 207 respondents described excessive funding as not having any relationship with the presence or absence of corruption in the public health sector while 21 respondents that represent $6.7 \%$ of the respondents did not give out their position on the issue. The interpretation of the above table clearly reveals that excessive government funding of the public health sector is not a determining factor for the presence or absence of corruption. The above assertion was better presented by Bello and Adetona, (2009) when the posit that "bribes corrupt officials, inadequate personnel and mis-procurement undermine health care delivery in much the same way they do for police services, law courts and customs whose functions become compromised by the culture of poor governance and corruption."

\section{Testing of Hypothesis}

To test for the hypothesis formulated, Chi-square $\left(\chi^{2}\right)$ test of independence will be used. The decision rule will be to accept the alternative hypothesis (H1) if the Chi-square calculated is greater than the chi-square tabulated and reject the null hypothesis accordingly. If the chi-square tabulated is greater than chi-square calculated, the decision rule will be to accept the null hypothesis and reject the alternative hypothesis.

The observed frequency table

\begin{tabular}{|l|l|l|l|l|l|}
\hline Question & A & B & C & D & Total \\
\hline 1 & 213 & 31 & 68 & 0 & 312 \\
\hline 2 & 61 & 23 & 207 & 21 & 312 \\
\hline Total & 274 & 54 & 275 & 21 & 624 \\
\hline
\end{tabular}

$\mathrm{E} 11=\underline{312 \times 274}=137 \quad \mathrm{E} 12=\frac{312 \times 54}{624}=27 \quad \mathrm{E} 13=\frac{312 \times 275}{624}=137.5$

$\mathrm{E} 14=\underline{312 \times 21}=10.5$

624

Expected frequency

\begin{tabular}{|l|l|l|l|l|l|}
\hline Question & A & B & C & D & Total \\
\hline 1 & 137 & 27 & 137.5 & 10.5 & 312 \\
\hline 2 & 137 & 27 & 137.5 & 10.5 & 312 \\
\hline Total & 274 & 54 & 275 & 21 & 624 \\
\hline
\end{tabular}

$\chi^{2} \mathrm{Cal}=\underline{(\mathrm{oij}-\mathrm{Eij})^{2}}$

Eij

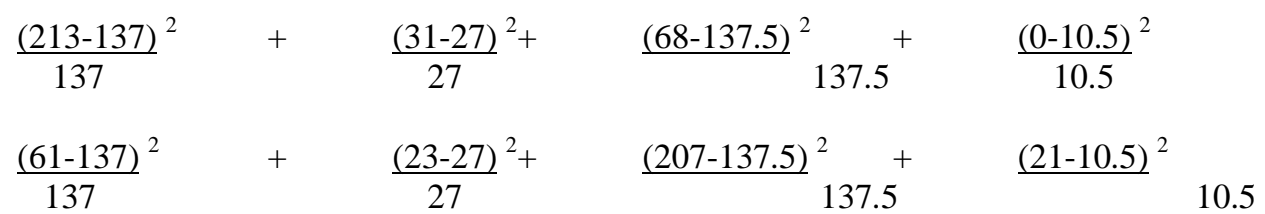

$=42.2+0.6+35.1+10.5+42.2+0.6+35.1+10.5=176.8$

$\chi^{2} \mathrm{tab}=\chi^{2} \alpha_{(\mathrm{r}-1)(\mathrm{c}-1) \mathrm{r}=2, \mathrm{c}=4}$ 


$$
\begin{aligned}
& =0.05(2-1)(4-1) \\
& =0.05(1)(3) \\
& =0.05(3)=7.815 \\
& \chi^{2} \text { calculated }=176.8, \chi^{2} \text { tabulated }=7.815
\end{aligned}
$$

\section{Decision Rule:}

Comparing the $\chi^{2} \quad$ calculated and the $\chi^{2}$ tabulated one will observe that $\chi^{2}$ calculated is greater than $\chi^{2}$ tabulated. The researcher will therefore accept the Alternative hypothesis (H1) and reject the null hypothesis (H0) and conclude that there is mis-management of fund in the Nigerian health sector and this has created a chance for the diversion of fund meant for the improvement of medical facilities to the personal purse of top government officers.

\section{Conclusion}

This study is an attempt at analyzing how the application of the Blue Ocean Strategy will help in enhancing service delivery in the Nigerian health sector. The misplacement of official interest for personal benefit that has characterized the Nigeria bureaucratic settings has in no small way curtailed the extent to which national development is achieved. It was discovered through this study that government spending on public health sector is very low and that is why the quality of medical service rendered was very poor and that the withdrawer of government funding will seriously affect the lower cadre of the society more. Also that the level of corrupt practices in the health sector has led to the diversion of fund from the procurement of medical equipment to private pockets, hence the inadequacies of medical equipment in the various public health institutions.

\section{Recommendations}

The following recommendations are suggested with the belief that their application will bring about the desired change in the Nigerian health service sector as well as other sectors in the economy. Facts deduced from the gathered data, empirical suggestions as well as personal observation of the researcher form the foundation of these recommendations and they are as follow;

a) Nigerians are entitled to nothing less than absolute honesty and total commitment in the performance of the public service. Therefore, honesty is a debt which the public service must pay in return for the trust reposed in it by the citizenry.

b) Good governance in the health sector generally refers to the enhancement of the stewardship functions and the improvement of management support system of both the national and local governments in terms of their collective responsibility for the overall performance of the health system (Bello and Adetona, 2009). It is therefore recommended that stewardship function and improved management support system should be incorporated in the activities of the public service.

\section{References}

[1]. Bello, R.A and Adetona O, (2009). "Good Governance and Performance of the Health System in Nigeria: A Framework for policy Analysis" in LIJOMASS, Lapai International Journal of Management and Social Sciences, Vol 2, Number 1, Lapai: Faculty of Management and Social Sciences, Ibrahim Badamosi Babangida University, Lapai, Niger State: 188-199

[2]. Bolarinwa, J.O and Aderogba, A.A, (2009). Bureaucratic Corruption in Africa: The Futility of Cleanups, International Journal of Sustainable Development, Vol 2, Number 2: Accra (Ghana), Pan-African Book Company: 74-84

[3]. Mii-Liis Liiv, (2004). The Causes of Administrative Corruption: A Thesis Submitted to the Department of Public Administration: University of Tartu, Faculty of Social Sciences

[4]. Myint, U. (2000) Corruption: Causes, Consequences and Cures Asia-Pacific Development, Journal Vol. 7, No. 2

[5]. Ogundiya, I.S. (2011). "Anti-Corruption Reforms in Nigeria: Challenges and Failures" in Assessment of Democratic Trends in Nigeria, New Delhi: Gyan Publishing House S.E Oganye, (2009). An Assessment of the Impact of Political Corruption on the Nigerian Economy; Ankpa Journal of Arts and Social Sciences, Vol 4, Number 1, Ankpa: School of Arts and Social Sciences, Kogi State College of Education: 73-85

[6]. Oosterbroek, J.W. (2007) Curtailing Corruption in the European Union University of Twente Centre for European Studies Enschede, Netherlands

[7]. Ramatu, N. (2008). NAVC An Antidote to Corruption" in Monitor, Vol 1, Issue 4, Abuja: Macpat Innovative Creations Ltd

[8]. W. Chan Kim and R. Mauborgne, (2005). Blue Ocean Strategy: United States, Harvard Business School Press

[9]. Victor E. Dike--- www.AfricaEconomicAnalysis.org

[10]. www.blueoceanstrategy.com 